Article

\title{
Perceptions and Role of Tourist Destination Residents Compared to Other Event Stakeholders in a Small-Scale Sports Event. The Case of the FIS World Junior Alpine Ski Championships 2019 in Val di Fassa
}

\author{
Filippo Bazzanella $(\mathbb{D}$ \\ Department of Strategic Management, Marketing and Tourism, Faculty of Business and Management, \\ University of Innsbruck, Karl-Rahner-Platz 3, 6020 Innsbruck, Austria; filippo.bazzanella@student.uibk.ac.at; \\ Tel.: +43-512-507-9560
}

Received: 4 October 2019; Accepted: 30 November 2019; Published: 4 December 2019

\begin{abstract}
The role of stakeholders is critical in addressing challenges with or problems in small-scale sports events. The purpose of this study is to investigate the perceptions of the event stakeholders toward sports events, with a particular focus on the role of residents in a tourist destination. The goal is to understand their perceptions with respect to different topics and in particular to the sustainable development of the tourist destination. This case study focuses on the World Junior Alpine Ski Championships 2019 in Trentino Val di Fassa-Italy (JWC2019). Applying a mixed methodology, the study analyzes the stakeholders during the sports event (quantitative method) and the point of view of the residents in their stakeholder role after the sports event (qualitative method). The main findings of this study show that residents differ from tourists and other stakeholders in terms of their perception of the event and its strengths. But when it comes to the perceptions regarding the territory, the groups of stakeholders analyzed do not seem to have systematically different opinions. Some paradoxes do, however, emerge with respect to the residents' awareness of their role as stakeholders and the implications of the event with respect to sustainability and how such an event may underpin a concept of sustainable development for the territory as a whole.
\end{abstract}

Keywords: small-scale events; stakeholder theory; event tourism; sustainable tourism; post-event analysis; residents' perceptions

\section{Introduction}

Sport event tourism became a research topic at the beginning of the 1990s as underlined by different scholars [1,2]. In recent decades, the interest of the academic community in events in a tourism context has increased greatly. Sport can also play a decisive role in the realm of sustainable development by adopting in particular policies aimed at paying greater attention to the environment [3]. The author presents a descriptive analysis of a small-scale sports event, taking into consideration a case already analyzed ex ante by the author in a previous study [4]. There is still a clear research gap in the various areas of analysis for small-scale events from a local perspective, given that many studies have chiefly focused on the economic impact [5]. The need to frame the role of the residents more clearly as stakeholders of the destination involved in organizing a small-scale sports event is clear both in theoretical and practical terms. This document takes into consideration the perspective of small-scale sports events in a tourism context, and analyzes the behavior and perceptions of the different stakeholders involved. It also explores whether this type of event is perceived as an effective contribution to the sustainable development of the tourist destination. Based on residents' perceptions, the research also tries to understand whether a "minor" event like the World Junior Alpine Ski 
Championships Trentino-Val di Fassa 2019 (JWC2019), if well managed, can represent a boost/support for events of greater importance.

The post-event analysis allows an assessment of the residents' perceptions, whereas pre-event research [4] investigates perceptions among other stakeholders of the same event. As far as the area of stakeholder theory is concerned, a pioneering study [6] defines stakeholder as "any group or individual that can affect or be affected by the achievement of a corporation's purpose". This concept has seen successive evolutions and has taken different trajectories depending on the field or sub-field in which it was considered.

Freeman's definition [6] is widely used in the literature even though other definitions are frequently applied in the broadest sense of the term [7,8]. Freeman himself [6] suggested the adoption by organizations or companies of specific strategies aimed at stakeholders, their understanding and their activation. Other authors $[9,10]$ have likewise developed ideas in this direction, deepening the concept of the stakeholder strategy matrix to create a useful tool for understanding the interests and potential of stakeholders, while providing management with a key for enhancing corporate strategies and governing the stakeholder phenomenon so that it is functional to business success.

More recently, according to research [11] highlighting one of the first approaches of stakeholder theory to the specific sub-field of event management-bearing in mind that when we talk about events we always talk about organizations [7] - the organization can also be defined as a system made up of groups of stakeholders and "failure to retain the participation of a primary stakeholder group will result in the failure of that corporate system" [7] (p. 107). As stated by Van Niekerk [12], "the essential premise of the stakeholder theory is that the organization should have a relationship with its stakeholders in order to be successful" [12] (p. 165).

In agreement with Byrd [13], it can be asserted that, to ensure sustainable tourism development at a destination with an important asset in the events, the stakeholders in the events must also be involved in the event management process.

Even small-scale events attract many stakeholders, including local residents, who can play an important role in all organizational phases. Residents are often instrumental both in the decision-making phase of the bidding processes and in the operational phases of event organization, as asserted by Preuss and Solberg [14]: "Local and national residents play an important role in this process as their opinion will influence whether the political system supports the application and is willing to fund the event." [14] (p. 391). While the scholars are insightful, they are fairly fragmented and mainly focus on a single factor or process. It is clear that the contribution of residents to the tourist development of the destination is influenced by the perception of a positive personal benefit [15]. Therefore, it is necessary to deepen the role of local residents as stakeholders in small-scale sports events and to explore the factors that influence the events themselves (small-scale events and, through their capacity and stimulus, even the largest ones) and the residents in terms of sustainable territorial development.

Based on the above premises and carefully observing the case study (ex ante research) [4] that inspired this new research, this study examines the following three questions:

RQ1: What are the perceptions of the various stakeholders during a small-scale sports event? Do the perceptions of tourist destination residents match those of other stakeholders?

RQ2: In the eyes of the residents, what is the perception of sustainable development in the context of a small-scale sports events in a tourist destination? Is it considered a "must have"?

RQ3: What role may small-scale sports events play when hosting mega events? Does a small-scale sports event represent a development stimulus for a tourist destination?

To answer these research questions, the case of the JWC2019 was selected. The article consists of the following parts: Theoretical background which includes the literature review. In the data and method section, light is shed on the methodology and subsequent data analysis. This is followed by the results of the study and the subsequent discussion arising from the analysis as well as the implications, the limitations of the study and the conclusions. 


\section{Theoretical Background}

This section aims to develop some notions useful to the general definition of the overall theme addressed by the present research.

\subsection{Tourism and Sport Tourism}

Tourism was one of the fastest growing sectors in 2018 with growth amounting to $3.9 \%$ (global economy 3.2\%) and future projections remaining positive [16]. As stated by Duglio, Beltramo [17]: "Mountains are the second most popular tourism destinations in the world, following coast and island resorts." [17] (p. 29). The relationship between tourism and sport has attracted considerable attention in tourism research. Among the most practiced and widely researched sports in mountain tourism is skiing. Ski tourism is a mature and very important world market. In recent decades, its evolution has interested all stakeholders in the reference market but now the issue of climate change is raising new scenarios [18].

As mentioned earlier, the theme of sport tourism has been studied in depth [19-23]. The studies on this topic have contributed to defining the phenomenon of sport tourism and tracing its boundaries and future perspectives within a frame of research questions that remain unanswered or aspects of which are yet to be investigated. Weed, in particular, highlights the state of maturity of this research sector and the emergence of different schools of thought and perspectives that are not always shared. In their meta-review analysis, Van Rheenen, Cernaianu and Sobry [24] defined the epistemological frame of the sport tourism area for the coming years. The confluence between sport and tourism leads to a very conspicuous series of definitions. For sport tourism, we can therefore include the different levels of sport involvement in tourism [25]. Getz [1] proposes a framework of analysis with respect to the research topic of event tourism. He does this by looking for intersections between studies on tourism management/tourism studies and event management/event studies. In defining the perimeter of the study, we also have to consider the potential effects of climate change, the impacts of which will be difficult to predict. As far as sport tourism, ski tourism and outdoor sports are concerned, we will certainly see negative effects on winter sports tourists, as indicated by the study of Askew and Bowker, [26] which examines the geographical area of the United States with a projection to 2060.

\subsection{Sustainable Development}

This term is often abused but, considered in its broader meaning, it is clearly a fundamental issue, also in terms of tourism and sports events. The evolution of the concept of sustainable development $[27,28]$ brings us closer to the notion of sustainable tourism or sustainable events. The definition of Duran, Artene, Gogan and Duran [29] appears useful for the general framework of the theme: "A sustainable development must be backed up by economic growth" [29] (p. 812). The theme of sustainability applied to tourism appears in the 90s and was later associated with the field of events and sports events. Numerous studies address the issue of sustainability in conjunction with events from different angles [30-32]. It is interesting to note how "green events" can influence the behavior of the stakeholders involved [33]. Elkington's research [34] has shown that the effects of the active involvement of the local community in the organization of a cultural event can lead to an improvement in the perception of the event itself on the outside and to the destination's sustainable development overall [35]. The issue of sustainable development of a local community through events has been widely debated and research has produced a broad spectrum of different literature [36-38]. The theme of sustainable destination development in the context of small-scale sports events certainly deserves further study. Much of the literature that deals with the issue of small-scale sports events focuses on economic sustainability $[39,40]$ or social sustainability [41]. In the study by Gibson et al. the most important indicators for defining the concept of sustainability are highlighted in the context of a small sports event [42]. 


\subsection{Small-Scale Sports Events}

The literature on events is very consistent and is useful for the purpose of the present scientific research which restricts the field to small-scale events. An initial classification of events [43] and its subsequent refinement [40] helps to complete the frame of reference for the different event categories. This list enables us to position the considered case-study event correctly as a small-scale event. The potential return of small-scale sports events for a destination has been analyzed by several studies $[5,30,44]$. Some measure and compare the economic impact between large and small-scale events $[45,46]$. In some cases, sports events represent one of the most important attractions for the tourist destination, causing serious losses in the case of cancellation [47]. The literature presents an important evolution also with respect to the issue of sustainability at small-scale sports events and their impact on destinations, which in most cases are rural or peripheral areas rather than cities or areas with strong urbanization [42,48-50]. There are several studies that document how small-scale sports events represent a form of sustainable tourism for communities [2,42]. Especially in small communities, their members represent a good percentage of the stakeholders who are creators and protagonists of the events [49].

\subsection{Event Perception by Different Stakeholders}

The scientific literature on the broad topic of stakeholders can only take inspiration from Freeman's original work [6]. Here, we find the first seeds of the Stanford Research Institute and the notion of the meaning of stakeholders. The next steps in the literature trace the development of the concept of stakeholders, their role within an organization and the definition of the theory $[7,8,51,52]$. We have also seen, however, a recent evolution [53] of the stakeholder concept that has been revised dynamically into stakewatcher and stakeseeker. Recently, the stakeholder theory has been applied to events where stakeholders can play a key role in determining the event's success. Many studies have focused more on identifying stakeholders and defining an adequate strategy [54-58]. While the role of stakeholders in festivals has been analyzed by several scientific studies [12,55,57,59], little research has been conducted into stakeholders in small-scale sports events. The research [56] of Parent, Kristiansen, Skille and Hanstand highlights how widely the perceptions of an event can differ between the various stakeholders, along with their role and associated pressures that, in extreme cases, may even have a bearing on the event's survival.

Finally, the research of Reid and Arcodia [11] clearly shows how the implementation of stakeholder theory and the adoption of a clear strategy for identifying and involving stakeholders in an event within the entire organizational process are key actions for the purpose of building effective competitive advantages. Competitive advantages, in the case of sports events, can also be translated into sustainable development strategies (2.2.) and/or sustainable tourism, as highlighted in $[13,60]$.

\subsection{Residents' Perception of Sports Events}

To explore residents' perceptions of and support for small-scale sports events, this study aims to develop a framework to explain this group's perceptions with a view to supporting tourism destination development. In an event of this type, it is useful and important to understand the role of the residents, their perceptions and degree of involvement in the organizational phases. Taking a new perspective, a different approach [61] to the evaluation of the perceptions (in this case of the tourists) is presented as a way of analyzing the spontaneous annotations of the observed. Literature has already analyzed the perceptions of residents with respect to major events [62-67]. A model based on social exchange theory [68] explains the existence of a cause-effect relationship attributable to the cost-benefit dichotomy that can decisively influence the residents' thinking or perception of the event. Support among residents is greater where costs are perceived to be lower than the benefits. The same results emerge in a post-event study [69], where residents even change position, from negative to positive after becoming aware that costs are lower than the perceived benefits. On the other hand, the study by 
Deccio and Baloglu [70] shows that the residents' attachment to the community does not determine whether or not they adopt a positive perception of the event's effects on the area.

More recently, though not strictly focused on events, some studies have analyzed the satisfaction of residents with respect to the tourist destination and the concept of tourist sustainability that the local brand would like to convey [71,72]. For the purposes of this study, the research of Schnitzer et al. [73] is particularly useful in understanding whether the residents' experience (in this case young people) of a minor event can influence the destination's decision to apply for a major event (in this case the Olympic Games).

\subsection{Study Design}

Some scholars have highlighted the importance of the characteristics that determine or classify a sports event as a small-scale event. [40,43]. All research questions in this study refer to a small-scale sports event, investigating several implications such as the perceptions of stakeholders in general and residents in particular.

As summarized in Figure 1, to address the research questions the author examined the event stakeholders (including the residents) through a quantitative research approach (questionnaire collected during the event) and subsequently performed a more in-depth analysis of residents through a qualitative research approach (focus group) in order to understand their perceptions of the event and its effects on the tourist destination and on the destination's development. The research starts with the identification of the event stakeholders and then moves on to a more in-depth analysis of the residents in an attempt to understand their identity and perceptions. This phase takes us in two directions that have a common link in the sports event: On the one hand, the sports event is seen as a way of possibly espousing the destination's sustainable development. On the other hand, the sports event is always a possible stimulus for events of greater size and can, therefore, be seen as a means of developing the tourist destination. While deepening the appreciation of the residents' perceptions of the event under review, it seems useful to go beyond the concept of economic impact [30] and to investigate the event's sustainable output [49].

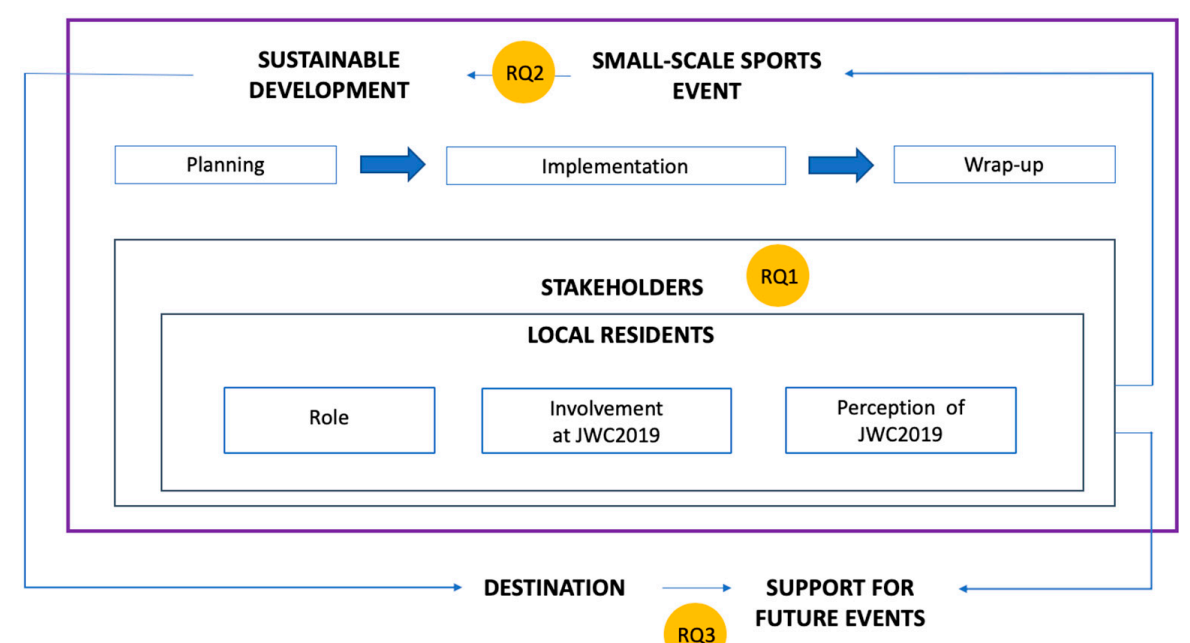

Figure 1. Study Design.

\section{Data and Methods}

\subsection{Contextual Background}

The small-scale event considered in the analysis is the JWC2019. Val di Fassa is located in the Trentino region of Italy (Figure 2a), in the heart of the Dolomites, a mountain range which has been declared a UNESCO World Heritage site. The Ladin community has learned how to safeguard its own 
language as well as the sustainability of the environment. The tradition of hospitality $(55,000$ beds and 4.4 million overnight stays) [74] has deep ties to this land: The facilities are state of the art, the services efficient and the range of things to do is wide and well considered. Val di Fassa is one of the capitals of international skiing thanks to more than $200 \mathrm{~km}$ of slopes for Alpine skiing. At the heart of the Dolomiti Superski carousel, the largest in the world, the skiing area is one of the most advanced, with the latest ski lifts, guaranteeing the maximum amount of ski time during the season.

The JWC2019 took place from 18 to 27 February. The program included downhill, supergiant, giant slalom, special and combined slalom competitions, both male and female, and a mixed team competition. More than 500 athletes and technicians from 54 countries gathered for ten days of competitions, during which 33 medals were awarded. The competitions were organized on two main slopes: "Aloch" in Pozza di Fassa (Figure 2b) and "La VolatA" on Passo San Pellegrino (Figure 2c), both of which underwent major renovation to host the JWC2019, placing part of the event's legacy at the disposal of the tourist destination. The location under examination could be involved in some way in the organization of the Milan-Cortina 2026 Winter Olympic Games (WOG2026), which were recently awarded to Italy by the International Olympic Committee (IOC).

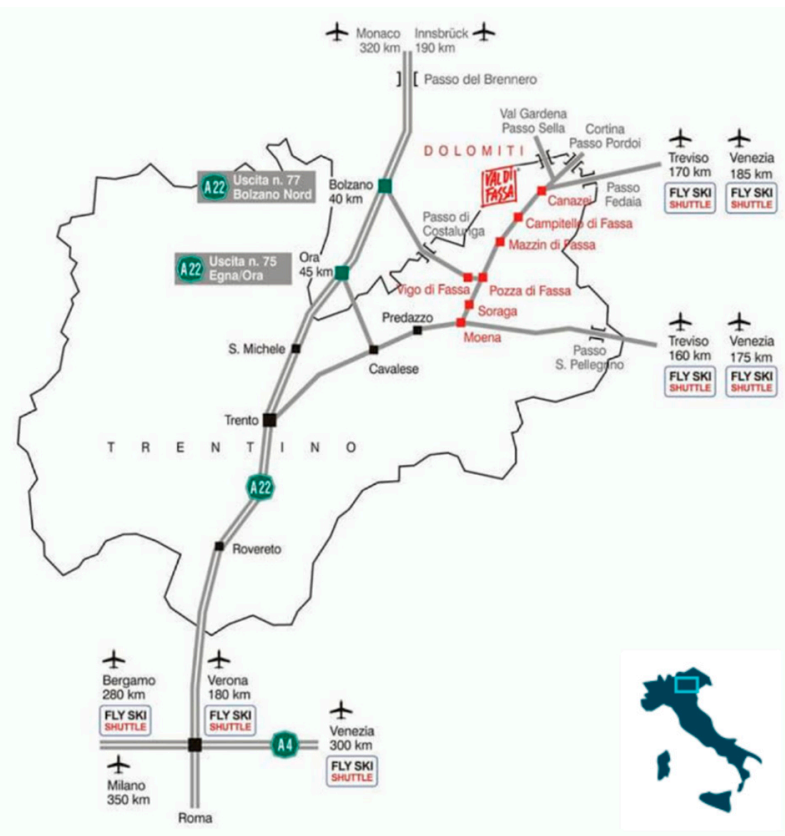

(a)

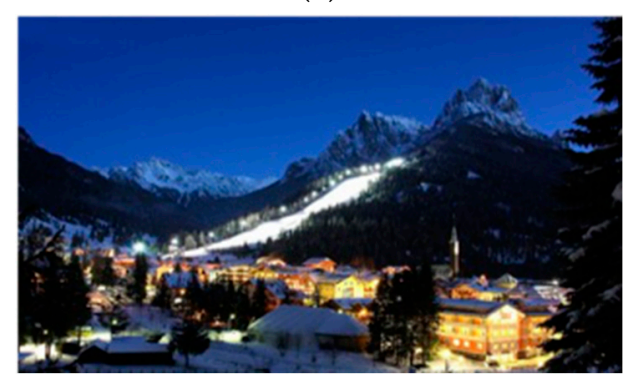

(b)

Figure 2. Cont. 


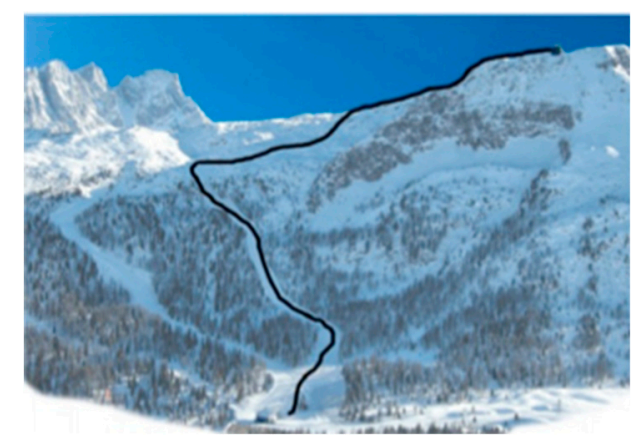

(c)

Figure 2. (a) The Val di Fassa-Trentino map (ITA) and (b) Aloch Ski Stadium of the World Junior Alpine Ski Championships 2019 in Val di Fassa-Italy (JWC2019), reconditioned in 2018. (c) La VolatA Slope for the JWC2019, renovated in 2018. Photo credits: (a-c) APT Val di Fassa.

\subsection{Procedures}

In order to provide answers to the research questions (RQs) and to discuss the different approaches of the literature in this field, a survey during the event and guided qualitative focus group interviews after the event were undertaken. A mixed research method [75-78] allowed the author to map the event stakeholders through the dataset analysis and subsequently through the focus groups to sharpen the focus of the stakeholders to local stakeholders, i.e., local residents.

This research method combines quantitative and qualitative data analysis in the same study, following the original definition of Tashakkori and Teddlie, [79] that: "Mixed methods studies are those that combine the qualitative and quantitative approaches into the research methodology of a single study or multiphased study" [79] (pp. 17-18). By combining the strengths and limitations of both research methods, there is likely to be a more coherent result when measuring the hypotheses relating to a given phenomenon [75]. In the first phase, a questionnaire was submitted and the interviewees $(\mathrm{N}=812)$ were the stakeholders of the event in a randomly collected sample. In the second phase, the author used a qualitative research method, that is, the focus group interviews to validate and deepen some of the data emerging from the proposed quantitative model. The interviewees comprised only local residents in the area affected by the event. The author created the research project by adopting the explanatory sequential mixed methods design [75]. The general intent of this project is to have qualitative data that helps to explain the initial quantitative results in more detail.

\subsubsection{Quantitative Study}

The author used a survey to measure the stakeholders' perceptions of JWC2019. In the mixed method approach applied, the quantitative opinion survey was used as a first study method in order to gain at least partial answers to some of the questions that were raised in this research.

The author used a survey administered during the event to measure the perceptions of residents and other stakeholders alike regarding several aspects of the JWC2019, its organization and the territory. The questionnaire was informed by previous qualitative research, ensuring the relevance of the concepts and dimensions measured. The survey was translated into the two most important languages spoken during the event: Italian and English. Respondents $(\mathrm{N}=812)$ were selected randomly during the JWC2019 whilst data collection was likewise randomly conducted at the event (between 18 and 27 February 2019) without a pre-defined sample. With the support of a specialized company, the Organizing Committee was already planning to submit a questionnaire to measure the strengths and weaknesses of the event as perceived by the stakeholders and to measure the recognizability of the sponsors/brands of the event. The author was involved in the organization and integrated the specific research interest in the questionnaires (socio-demographic data and eight specific questions). Since this was an on-site survey carried out on mobile devices (Apple IPad Pro Second Generation) based on a web platform, and not on paper, there were no discarded questionnaires, as all the answers from 
the completed questionnaires were recorded on the system. Finally, data was collected through the CAWI (Computer Assisted Web Interviewing) application. The questionnaires were administered by 12 high-school students, involved in a special school project during the organizational phases of the event. The students received two specific briefings before the questionnaires were distributed. The author took care of the briefings together with the company that managed the web platform and the implementation of the digital questionnaire. The students were divided into six teams of two members each in line with recommendations $[76,80]$ for determining appropriate sample size. During the event the author remained in constant contact and held a daily briefing with the teams that administered the questionnaires to clarify any critical issues. Data was collected using different spatial method positions, from the sites involved in the JWC2019 event to other locations that had nothing to do with the event, and places that were densely frequented (public offices, restaurants, bars, ski lift stations).

A total of 812 questionnaire were completed. As reported in Table 1, the average respondent was a highly educated Italian male, younger than 40 years of age. In terms of the reason for being in Val di Fassa during the event, the sample is balanced, with slightly more than one third of respondents being residents, one third tourists and almost one third other stakeholders (athletes, staff members of a team, media, etc.).

Table 1. Survey sociodemographic profile of respondents $(\mathrm{N}=812)$.

\begin{tabular}{|c|c|c|}
\hline Demographic & $\mathbf{N}$ & $\%$ \\
\hline \multicolumn{3}{|l|}{ Gender } \\
\hline Male & 473 & 58,3 \\
\hline Female & 339 & 41.7 \\
\hline \multicolumn{3}{|c|}{ Age $($ years; mean $=38.58$, median $=38.11)$} \\
\hline$<20$ & 144 & 17.7 \\
\hline $20-30$ & 168 & 20.7 \\
\hline $31-40$ & 122 & 15.0 \\
\hline $41-50$ & 173 & 21.3 \\
\hline $51-60$ & 132 & 16.3 \\
\hline$\geq 61$ & 73 & 9.0 \\
\hline \multicolumn{3}{|l|}{ Origin } \\
\hline Italy & 520 & 64.0 \\
\hline Other countries * & 292 & 36.0 \\
\hline \multicolumn{3}{|c|}{ Origin of the Italian respondents $(N=520)$} \\
\hline Val di Fassa and Trentino Region & 263 & 50.6 \\
\hline Other regions & 257 & 49.4 \\
\hline \multicolumn{3}{|l|}{ Education $(\mathrm{N}=812)$} \\
\hline None & 17 & 2.1 \\
\hline Primary and secondary school & 168 & 20.6 \\
\hline High school & 352 & 43.3 \\
\hline University degree and Postgraduate (MSc and $\mathrm{PhD}$ ) & 275 & 33.9 \\
\hline \multicolumn{3}{|l|}{ Occupation $(\mathrm{N}=812)$} \\
\hline Students & 164 & 20.2 \\
\hline Employees & 275 & 33.9 \\
\hline Freelancers/Self-employed/Entrepreneurs & 197 & 24.3 \\
\hline Housewives & 20 & 2.5 \\
\hline Retired & 57 & 7.0 \\
\hline Unemployed & 10 & 1.2 \\
\hline Others & 89 & 10.9 \\
\hline
\end{tabular}


Table 1. Cont.

\begin{tabular}{ccc}
\hline Demographic & $\mathbf{N}$ & $\%$ \\
\hline Household monthly income $(\boldsymbol{\epsilon}) \mathbf{( N = \mathbf { 8 1 2 } )}$ & \\
$\leq 1000$ & 24 & 3.0 \\
$1001-2000$ & 88 & 10.8 \\
$2001-3000$ & 88 & 10.8 \\
$>3000$ & 172 & 21.2 \\
Not declared & 440 & 54.2 \\
\hline Stakeholder categories of respondents $\mathbf{( N = 8 1 2 )}$ & \\
Residents & 294 & 36.2 \\
Tourists & 274 & 33.7 \\
Other stakeholders & 237 & 29.2 \\
Do not know & 7 & 0.9 \\
\hline Note: ${ }^{*}$ respondents from 40 countries. &
\end{tabular}

In order to understand whether the residents' perceptions of the event and the territory differ from the perceptions of the two other groups (i.e., tourists and other stakeholders) the author used the chi-square test for independence and the Kruskal-Wallis Test.

The goal of the analysis is to compare the distribution of responses to a number of discrete outcome variables among several independent comparison groups (residents, tourists and other stakeholders). Whenever the dependent variable is binary, the author used a chi-square test to analyze whether there is a statistically significant difference in prevalence (proportion) between the three groups. A Kruskal-Wallis Test was instead utilized in the case of an ordinal outcome variable (score on the Likert scale). It is considered the nonparametric alternative to the one-way ANOVA, to allow the comparison of more than two groups, without imposing any normality assumption on the distribution of the data. Statistical significance was set at $p<0.05$. All statistical analyses were conducted using the SPSS Statistics 26.0 software (IBM Statistics, Armonk, NY, USA).

\subsubsection{Qualitative Study}

Focus group interviews were conducted after the event, inviting residents not necessarily involved in the event. As for the focus groups, Krueger [81] suggests continuing to run the focus group until no more significant data emerges, essentially with a view to achieving saturation $[82,83]$. Several authors suggest that in the case of less complex research, the number of focus groups needed could be limited to three or four [81]. Moreover, the optimal number of participants in each focus group can range between four and twelve, with the smaller groups being easier to manage; however, the significance of the results is likely to be greater in the larger groups, which are more difficult to manage. Krueger and Casey [84] suggest between six and eight participants, since past studies have shown that smaller groups perform better.

The recruitment of the focus group participants started with a list compiled by the researcher which included active members of the community such as representatives of municipal administrations and voluntary associations operating in the area. One of the essential conditions for participating in the focus groups was being a resident of Val di Fassa. The sampling technique [84] began with a list of people representing the destination's most recognized institutions. Once 3 potential participants had been identified, the author asked everyone to search for/appoint other people they considered useful or important for the purpose of studying their own territory. The sample was completed when the last person appointed did not provide any other names and the number of group members was considered sufficient. In essence, the author adopted what Scott [85] defines as a snowball technique.

The author, with a background in events and sports management, evaluated the layout of the interview and the validity of the content, and, following a comparison with other researchers and experts, modified the final layout. 
In total, three groups with 21 persons were involved from all over the valley. There were 14 males and seven females. $47.6 \%$ of respondents were under 40 years of age (a similar percentage to the survey where $53.4 \%$ of respondents were under 40 years of age). The details are shown in Tables 2 and 3.

Table 2. Residents' interviews and interview method.

\begin{tabular}{|c|c|c|c|c|c|}
\hline $\begin{array}{l}\text { Distinctive } \\
\text { Number of the } \\
\text { Focus Group }\end{array}$ & $\begin{array}{l}\text { Description Name of } \\
\text { Focus Group }\end{array}$ & $\mathbf{N}$ & Method & Date & Duration \\
\hline 1 & $\begin{array}{l}\text { Young Generation } \\
\text { Residents }\end{array}$ & 6 & In-person & 5 August 2019 AM & $43^{\prime} 53^{\prime \prime}$ \\
\hline 2 & $\begin{array}{l}\text { Upper Valley } \\
\text { Residents }\end{array}$ & 6 & In-person & 5 August 2019 PM & $53^{\prime} 46^{\prime \prime}$ \\
\hline 3 & $\begin{array}{l}\text { Lower and Middle } \\
\text { Valley Residents }\end{array}$ & 9 & In-person & 5 August 2019 PM & $46^{\prime} 06^{\prime \prime}$ \\
\hline
\end{tabular}

Table 3. Interviews sociodemographic profile of respondents $(\mathrm{N}=21)$.

\begin{tabular}{ccc}
\hline Demographic & $\mathbf{N}$ & $\mathbf{\%}$ \\
\hline \multicolumn{3}{c}{ Gender } \\
Female & 14 & 66.7 \\
Age (years; mean $=$ 38.58, median & $\mathbf{3 8 . 1 1 )}$ \\
$<20$ & 5 & 23.8 \\
$20-30$ & 1 & 4.8 \\
$31-40$ & 4 & 19.0 \\
$41-50$ & 1 & 4.8 \\
$51-60$ & 6 & 28.6 \\
$\geq 61$ & 4 & 19.0 \\
\hline
\end{tabular}

The author moderated all 3 focus groups. The discussion process was very interesting because subjects of different ages were represented, and each group saw group discussions continue without particular interference from the moderator who mainly introduced topics or keywords. Focus groups allow participants to discuss a specific topic freely and to express their opinions or clarify certain thoughts $[84,86]$.

All the focus groups were organized in private rooms, away from noisy and/or conditioning environments. Every respondent who wanted to contribute raised their hand, said their first name and started speaking. The moderator intervened as little as possible allowing the fluidity of the discussion.

Following Mayring [87], the author proceeded with the coding process. Many preliminary issues emerged from the analysis, all of which corresponded to a code and were classified through the MAXQDA software (version 2018.2—VERBI GmbH, Berlin, Germany).

Subsequently, the preliminary themes were analyzed, and the synthesis led to the identification of the main themes in which the preliminary themes came together. The narrative summary of the work completed can be found in the next section [88].

All the subjects participating in the research, both in the questionnaire and in the focus groups gave their informed consent for inclusion prior to participating in the study. The anonymity of the participants was always guaranteed and the participants were informed in advance of the aims of the study. Verbal informed consent was obtained from all participants prior to the start of the study. 


\section{Findings}

\subsection{Quantitative Analysis}

The sample was chosen in a random manner, suggesting that the results could be representative of the entire population. Indeed, in such a dynamic situation of testing during the sports events, there were simply no other options. Full randomization was not possible.

Table 4 illustrates the results of the Chi-Square Test. The first column displays the relevant question, as per the administered questionnaire. The number of observations drops to 805 , because seven of the interviewed individuals preferred not to state their reasons for visiting Val di Fassa. Thus, the author did not have enough information to assign these subjects to one of the groups (residents, tourists, other stakeholders).

In the first question (Q1) "Did you know that the World Junior Alpine Ski Championships 2019, which involves 335 athletes from 56 countries, is taking place in Val di Fassa?", the statistical analysis showed significant differences (Chi2 $=146.6, p<0.0001$ ). In fact, for residents the positive response (YES) was $94.9 \%$ and the negative one (NO) $5.1 \%$, while for the tourist category, the positive response (YES) was $64.6 \%$ and the negative one (NO) $35.4 \%$.

Table 4 shows that the three groups have different knowledge and perceptions regarding the event. If the $p$-value is smaller than the standard significance level of $5 \%$, we cannot accept the null hypothesis that the parameters (means) are equal. In particular, compared to the other groups, residents seem to assign less importance to the landscape as a reason for liking the event. This result could be somewhat expected, given that residents know and like (or dislike) their territory regardless of the event. Interestingly, they appear to value the organization, the people and the athletes more than the other stakeholders. Question two (Q2) — "What did you like most about the JWC2019?"—indicated statistical differences. The answers "Landscapes" (Chi2 $=13.1, p=0.001)$, "The Organization" (Chi2 = 10.5, $p=0.005)$, "The People" (Chi2 $=8.2, p=0.016)$ and "The athletes" (Chi2 $=7.8, p=0.020)$ showed a different distribution of percentages.

Table 5 illustrates the results of the Kruskal-Wallis Test, based on Likert scales which comprise ordinal data subject to a ranking in which 5 is more than 4 , and 4 is more than 3 , etc. The three groups have statistically significant different perceptions about the event's main features and the reasons for its success. In fact, the second panel of Table 5 shows that each item is statistically significant ( $p$-value smaller than the standard 5\% significance level), meaning that the three groups present differences related to the median.

Regarding Questions $3(\mathrm{Q} 3)$ and 4 (Q4), respectively, "How appropriate is each definition of Val di Fassa?" and "How appropriate is each definition of the JWC 2019?", some data present $p$-values showing different assessments between stakeholders of the definitions given for the tourist destination and the event. In Q3, the definitions "It is unique" and "It has friendly people" present some differences in the respective responses (Chi2 $=9.7, p=0.008)$ and (Chi2 $=22.6, p=0.000)$. In $\mathrm{Q} 4$, the definitions "It is entertaining", "It is thrilling", "It is international", "It is fair/well regulated", "It is high class" present differences in the respective responses (Chi2 $=20.6, p=0.000),(\mathrm{Chi} 2=15.2, p=0.001)$, (Chi2 $=$ 34.7, $p=0.000)$, (Chi2 $=16.4, p=0.000),($ Chi2 $=11.2, p=0.004)$. While the differences in the medians are minimal, they need to be examined further to understand the dynamics that led the residents to make different evaluations.

For Questions 5-8-(Q5) "How satisfied were you with the World Junior Alpine Ski Championships 2019 in Val di Fassa?", (Q6) "Would you recommend your friends and family to follow live high-level sports events in Val di Fassa (Alpine Skiing World Cup, Cross Country World Cup etc ... )?", (Q7) "Will you attend other live events (Alpine Skiing World Cup, Cross Country Skiing World Cup ... ) in Val di Fassa?" and (Q8) "Did your visit to Val di Fassa leave you with the desire to come back in the future?"- the $p$-value shows that there are differences in the responses from the various stakeholders. The median of the responses (for which a Likert scale was used) from the stakeholder groups is statistically different. 
Table 4. Awareness among stakeholders of JWC 2019 ( $\mathrm{N}=805)$.

\begin{tabular}{|c|c|c|c|c|c|c|c|c|}
\hline \multirow{3}{*}{ Question } & \multicolumn{6}{|c|}{ Stakeholder Categories of Respondents $(\mathrm{N}=805)$} & \multirow{3}{*}{$\begin{array}{l}\text { Chi-Sq } \\
\text { Value }\end{array}$} & \multirow{3}{*}{$p$-Value } \\
\hline & \multicolumn{2}{|c|}{$\begin{array}{c}\text { Residents }(\mathrm{N}=294) \\
\%\end{array}$} & \multicolumn{2}{|c|}{$\begin{array}{c}\text { Tourists }(\mathrm{N}=274) \\
\%\end{array}$} & \multicolumn{2}{|c|}{$\begin{array}{c}\text { Other Stakeholders }(\mathrm{N}=237) \\
\%\end{array}$} & & \\
\hline & YES & NO & YES & NO & YES & NO & & \\
\hline $\begin{array}{l}\text { Q1-Did you know that the World } \\
\text { Junior Alpine Ski Championships 2019, } \\
\text { which involves } 335 \text { athletes from 56 } \\
\text { countries, is taking place in Val di Fassa? }\end{array}$ & 94.9 & 5.1 & 64.6 & 35.4 & 97.9 & 2.1 & $X^{2}=146.6$ & $p<0.0001$ \\
\hline $\begin{array}{l}\text { Q2-What did you like most about the } \\
\text { World Junior Alpine Ski Championships } \\
\text { 2019? }\end{array}$ & YES & NO & YES & NO & YES & NO & & \\
\hline The landscapes & 51.1 & 36.5 & 63.5 & 36.5 & 67.6 & 32.4 & $X^{2}=13.1$ & $p=0.001$ \\
\hline The ski runs & 47.6 & 52.4 & 51.0 & 49.0 & 54.3 & 45.7 & $X^{2}=1.9$ & $p=0.375$ \\
\hline The organization & 55.0 & 45.0 & 35.4 & 64.6 & 48.1 & 51.9 & $X^{2}=10.5$ & $p=0.005$ \\
\hline The hospitality & 16.6 & 83.4 & 26.0 & 74.0 & 24.3 & 75.7 & $X^{2}=5.4$ & $p=0.066$ \\
\hline The people & 24.0 & 76.0 & 15.6 & 84.4 & 13.8 & 86.2 & $X^{2}=8.2$ & $p=0.016$ \\
\hline The athletes & 27.5 & 72.5 & 13.5 & 86.5 & 21.4 & 78.6 & $X^{2}=7.8$ & $p=0.020$ \\
\hline The spirit of competition & 15.7 & 84.3 & 13.5 & 86.5 & 19.5 & 80.5 & $X^{2}=2.0$ & $p=0.362$ \\
\hline
\end{tabular}


Table 5. Stakeholders' perceptions, satisfaction and future vision regarding the territory and the event $(\mathrm{N}=805)$.

\begin{tabular}{|c|c|c|c|c|c|c|c|c|}
\hline \multirow{3}{*}{ Question } & \multicolumn{6}{|c|}{ Stakeholder Categories of Respondents $(\mathrm{N}=805)$} & \multirow{2}{*}{\multicolumn{2}{|c|}{ Kruskal-Wallis-Test }} \\
\hline & \multicolumn{2}{|c|}{ Residents N $=294$} & \multicolumn{2}{|c|}{ Tourists $\mathrm{N}=274$} & \multicolumn{2}{|c|}{ Other Stakeholders N = 237} & & \\
\hline & $\mathbf{M}$ & SD & M & SD & $\mathbf{M}$ & SD & & \\
\hline \multicolumn{9}{|c|}{ Q3-How appropriate is each definition of Val di Fassa * } \\
\hline It has good infrastructure & 4.3 & 0.7 & 4.2 & 0.8 & 4.2 & 0.8 & $X^{2}=7.7$ & $p=0.057$ \\
\hline It is beautiful & 4.7 & 0.6 & 4.7 & 0.6 & 4.7 & 0.5 & $X^{2}=1.9$ & $p=0.389$ \\
\hline It is international & 4.3 & 0.8 & 4.3 & 0.7 & 4.4 & 0.8 & $X^{2}=2.7$ & $p=0.260$ \\
\hline It is unique & 4.3 & 0.9 & 4.1 & 0.8 & 4.3 & 0.8 & $X^{2}=9.7$ & $p=0.008$ \\
\hline It is thrilling & 4.3 & 0.8 & 4.2 & 0.7 & 4.2 & 0.8 & $X^{2}=5.2$ & $p=0.074$ \\
\hline It is different & 4.1 & 0.9 & 4.0 & 0.8 & 3.9 & 0.9 & $X^{2}=2.1$ & $p=0.342$ \\
\hline It has friendly people & 4.1 & 0.9 & 4.3 & 0.7 & 4.4 & 0.7 & $X^{2}=22.6$ & $p=0.000$ \\
\hline It has wonderful landscapes & 4.8 & 0.4 & 4.8 & 0.5 & 4.8 & 0.4 & $X^{2}=2.3$ & $p=0.310$ \\
\hline It is exclusive & 3.9 & 1.0 & 3.8 & 1.0 & 3.9 & 0.9 & $X^{2}=0.5$ & $p=0.800$ \\
\hline \multicolumn{9}{|c|}{ Q4-How appropriate is each definition of the World Junior Alpine Ski Championships 2019?* } \\
\hline It is entertaining & 4.3 & 0.7 & 3.9 & 0.8 & 4.3 & 0.8 & $X^{2}=20.6$ & $p=0.000$ \\
\hline It is thrilling & 4.3 & 0.8 & 4.0 & 0.8 & 4.3 & 0.8 & $X^{2}=15.2$ & $p=0.001$ \\
\hline It is international & 4.6 & 0.7 & 4.2 & 0.8 & 4.6 & 0.6 & $X^{2}=34.7$ & $p=0.000$ \\
\hline It is trendy & 3.9 & 1.0 & 3.9 & 0.8 & 4.1 & 0.8 & $X^{2}=5.8$ & $p=0.055$ \\
\hline It is fair/well regulated & 4.3 & 0.8 & 4.1 & 0.7 & 4.4 & 0.7 & $X^{2}=16.4$ & $p=0.000$ \\
\hline It is high class & 4.4 & 0.7 & 4.1 & 0.8 & 4.3 & 0.8 & $X^{2}=11.2$ & $p=0.004$ \\
\hline It is unique & 4.2 & 0.9 & 4.0 & 0.8 & 4.2 & 0.8 & $X^{2}=10.7$ & $p=0.005$ \\
\hline It is family-oriented & 4.1 & 0.9 & 3.9 & 0.8 & 3.9 & 0.9 & $X^{2}=10.5$ & $p=0.005$ \\
\hline $\begin{array}{l}\text { Q5-How satisfied were you with the World Junior Alpine Ski } \\
\text { Championships } 2019 \text { in Val di Fassa? ** }\end{array}$ & 4.5 & 0.6 & 4.2 & 0.7 & 4.5 & 0.6 & $X^{2}=24.5$ & $p=0.000$ \\
\hline $\begin{array}{l}\text { Q6-Would you recommend your friends and family to follow } \\
\text { live high-level sports events in Val di Fassa (Alpine Skiing } \\
\text { World Cup, Cross Country World Cup etc ... )? *** }\end{array}$ & 4.5 & 0.7 & 4.3 & 0.8 & 4.6 & 0.6 & $X^{2}=20.2$ & $p=0.000$ \\
\hline $\begin{array}{l}\text { Q7-Will you attend other live events (Alpine Skiing World } \\
\text { Cup, Cross Country Skiing World Cup ... ) in Val di Fassa? ** }\end{array}$ & 4.5 & 0.7 & 4.2 & 0.9 & 4.5 & 0.7 & $X^{2}=17.0$ & $p=0.000$ \\
\hline $\begin{array}{l}\text { Q8-Did your visit to Val di Fassa leave you with the desire to } \\
\text { come back in the future? }\end{array}$ & 4.7 & 0.7 & 4.6 & 0.5 & 4.5 & 0.7 & $X^{2}=16.5$ & $p=0.000$ \\
\hline
\end{tabular}

Note: * Items were assessed on a five-point Likert scale (1. definitely not appropriate and 5. completely appropriate). ${ }^{* *}$ Items were assessed on a five-point Likert scale (1. very unsatisfied and 5. very satisfied). ${ }^{* * *}$ Items were assessed on a five-point Likert scale (1. very unlikely and 5. very likely). 
The author concludes that residents do indeed differ from tourists and other stakeholders in terms of their perceptions regarding the event and its strong points. When it comes to perceptions related to the territory, the three groups do not seem to have systematically different opinions.

\subsection{Analysis of the Focus Group Interviews}

The focus groups involved only the residents as specified in paragraph 3.2.2. The main results are determined at the end of Section 4.2.4., based on the issues that emerged after the analysis and coding.

To facilitate understanding of the subsequent narrative, the author has summarized the most significant results of the analysis in Table 6, showing the primary and secondary categories, formed through the coding in the analysis of the focus groups, as well as the main themes that have been determined (tourist destination, small-scale sports event, stakeholders).

Table 6. Categorization of coding.

\begin{tabular}{|c|c|c|}
\hline Primary Category & Secondary Category & Main Theme \\
\hline $\begin{array}{l}\text { Be a community } \\
\text { Environment } \\
\text { Volunteers }\end{array}$ & Awareness and Expectations & \multirow{2}{*}{ Tourist destination } \\
\hline $\begin{array}{c}\text { Culture and linguistic minority } \\
\text { Young people } \\
\text { Promotion }\end{array}$ & Image & \\
\hline $\begin{array}{l}\text { Organization } \\
\text { Critical issues }\end{array}$ & Strengths and Weaknesses & \multirow{4}{*}{ Small-scale sports event } \\
\hline $\begin{array}{c}\text { Sport }=\text { positive message } \\
\text { Competitors }\end{array}$ & Values & \\
\hline $\begin{array}{l}\text { Positive } \\
\text { Negative }\end{array}$ & Legacy & \\
\hline $\begin{array}{l}\text { Mega events and expectations } \\
\text { More continuity }\end{array}$ & Future & \\
\hline $\begin{array}{l}\text { Bottom-up } \\
\text { Top-down } \\
\text { Involvement }\end{array}$ & Approach & \multirow[t]{2}{*}{ Stakeholders (Residents) } \\
\hline $\begin{array}{l}\text { Collective } \\
\text { Single }\end{array}$ & Return & \\
\hline
\end{tabular}

\subsubsection{The Tourist Destination}

In the focus groups, a word cloud was used in Figure 3a to explain the results. We see that landscape and beauty stand out alongside concepts such as well-being and nature. However, terms such as sport, tourism, snow and culture are also included, which point to an awareness of the mountain territory and its vocation in hospitality and in offering active holidays, given the morphology of the territory and the infrastructures with which it is equipped. This can be better understood by providing some quotations that widen the considerations emerging from the word cloud, and by introducing those we have codified and can be considered sub-themes:

\section{AWARENESS AND EXPECTATIONS}

This subgroup focused on what residents make of their home territory, the most salient characteristics that define it and their expectations of the future. The assessments were sentimental but also objective, based on concrete aspects. 
Be a Community

"We must say thanks to the abilities of individuals and small groups but it would be better to have a valley involvement. With the potential of the Val di Fassa we could have the world here." Gr2-member1.

\section{Environment}

"Perhaps we need to pay more attention to the environment and the territory, not because we didn't guarantee enough in the case of the JWC2019, but because in the future environmental sustainability will be increasingly important." Gr3-member7

\section{$\underline{\text { Volunteers }}$}

"I feel proud of my territory, very much and I saw that in volunteering there were people from all villages, there was no parochialism. This is a very very positive thing." Gr2-member1

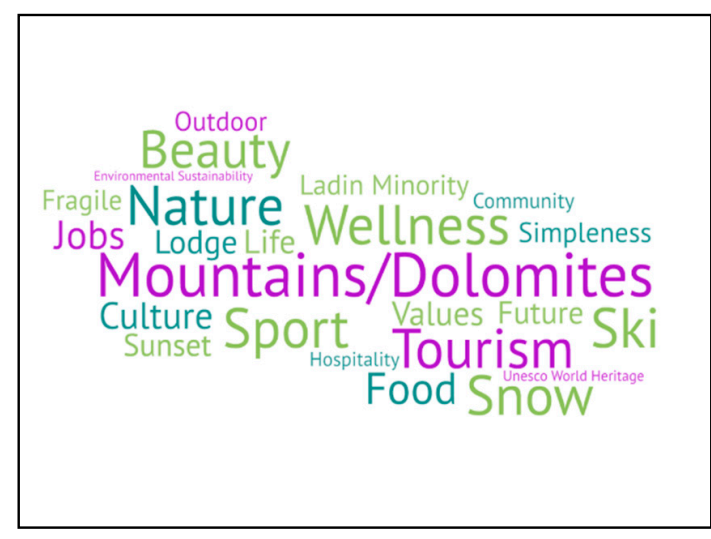

(a)

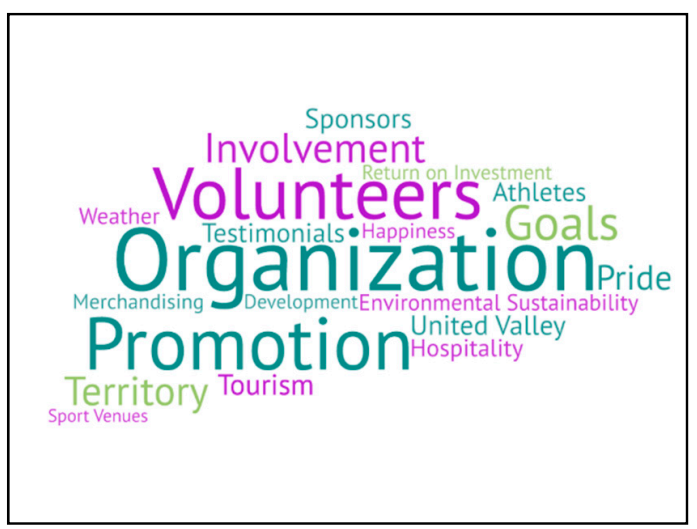

(c)

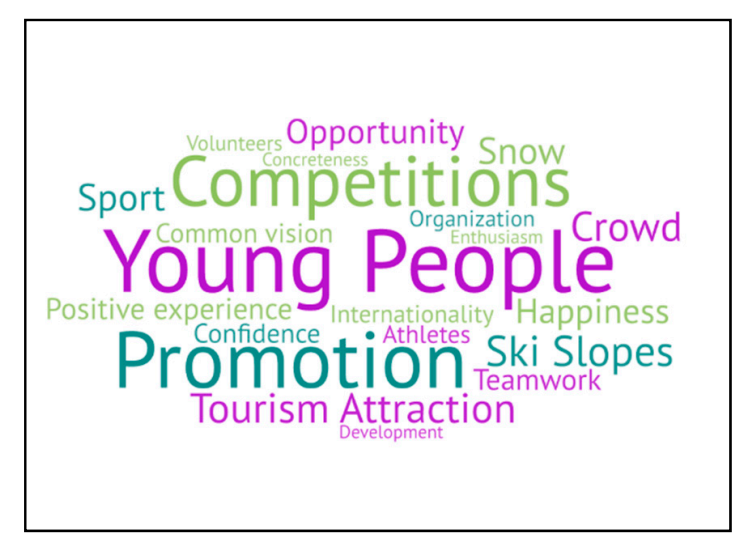

(b)

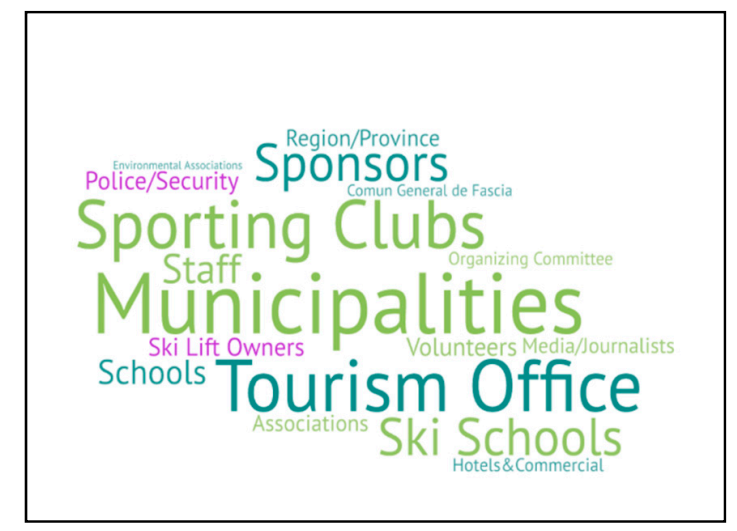

(d)

Figure 3. Resident focus group perceptions (a) Val di Fassa in words; (b) JWC2019 in words; (c) the "must haves" for a sports event; (d) stakeholders in JWC2019.

\section{IMAGE}

In the previous subgroup, the comments were more from the heart, expressing a sense of belonging to a community. In this sub-group, however, the comments were characterized by a sense of realism, and an evaluation of the return generated by a sports event in terms of the region's image, which can be perceived in different ways. 
Culture and Linguistic Minority

"I think it is a point that we have more thanks to the linguistic minority. It is a strength that we must exploit." Gr3-member3

Young People

"I really enjoyed seeing them, more beautiful to see young people having fun than seeing more famous athletes." Gr1-member5

\section{Promotion}

"Thanks to TV images and organizational success we have certainly gained in credibility and improved the reputation." Gr3-member8

\subsubsection{The Small-Scale Sports Event (JWC2019)}

The focus groups also tackled the issue of stakeholders in the event. Figure $3 b$ shows the keywords that emerged from the interviewees. The emotional aspect linked to the JWC2019 as directly lived by the residents, leads to the emergence of overwhelming themes such as: Youth, competitions and promotion. These themes are also evident in the following quotations which are organized in logical groupings. In Figure 3c, which features the words considered by the interviewees as "must haves", when compared to generic sports events, we see that the promotional aspect remains while organization, volunteering and objectives emerge together with territory and its own development.

\section{STRENGTHS AND WEAKNESSES}

Based on the large corpus of literature, sports events can have many different interpretations and, above all, different parameters to evaluate their effectiveness. In this section, the interviewed residents give their personal point of view on the best and worst aspects of this particular event that took place in their area.

$\underline{\text { Organization }}$

"I didn't follow much, but many people told me of a great success of the organization from the beginning up to all the involvement of the volunteers." Gr2-member3

\section{$\underline{\text { Critical Issues }}$}

"I noticed that both competition sites have structure limits and are not suitable for the World Cup." Gr2-member2

\section{VALUES}

In this group of sub-themes, the interviewees highlighted their impressions of the values that find expression in a sports event. These include both material values and intangible values, as well as positive and negative values such as envy or admiration.

$\underline{\text { Sport }=\text { Positive Message }}$

Gr1-member4"... In my opinion it is functional for the life of the valley to organize sports events because sport is an important asset." 
$\underline{\text { Competitors }}$

"There is a great desire in the Valley to do something great. We have always been suffocated by the levels of events of our neighbors and competitors Val Badia and Val Gardena." Gr3-member9

$\underline{\text { Sport }=\text { Promotion }}$

"Communication and TV have made the difference. They have promoted the territory worldwide." Gr3-member3

\section{LEGACY}

It was important in this part of the discussion to address all the possible nuances of what is considered the event's legacy. Similarly, it is interesting to understand whether a return is perceived in the short or long term, who or what will benefit most from the effects of the event, whether the staging of the event is considered positively at least in the short term and whether its organization as such represents a value beyond the economic aspect as well as many other aspects that touch upon the social fabric and the environment.

$\underline{\text { Positive }}$

"This world championship certainly will have a very long-term but also short-term image return." Gr3-member3

Negative

"In my opinion there was no return because few knew there was such an important event. Those who had a greater advantage were the athletes and the technicians." Gr2-member1

\section{FUTURE}

This sub-theme measures the respondents' views about the future and their expectations and dreams. The discussion here also focused on future challenges, and more important events, even including the Olympic Games.

Mega Events and Expectations

"Everyone thinks something bigger will come in the future. We certainly want to have something globally." Gr3-member5

More Continuity

"If there is a continuity the thing works but if it is an isolated event and an end in itself it leaves nothing." Gr1-member4

\subsubsection{The Stakeholders (Residents)}

The topic of stakeholders is central to the present study. Figure $3 \mathrm{~d}$ shows the main stakeholders identified by the respondents in relation to the JWC2019. These include various bodies that manage the destination's policies: The municipalities, the community, the tourist office. They also refer to other protagonists such as sponsors, or bodies more specifically related to the world of winter sports. 
Surprisingly, the volunteers are mentioned only on the periphery, whereas they were considered one of the top words in Figure 3c, indicating the "must haves". In the case of the JWC2019, the volunteers were therefore considered important but not as stakeholders. In the discussion, the theme of volunteering was addressed several times. In the word clouds and the focus group discussions, no one ever considered the residents as stakeholders.

\section{APPROACH}

One of the most interesting focus group discussions explored the methods adopted by a sports event organizing committee in approaching and managing the stakeholders. The majority expressed a preference for an inclusive and upfront modality, where most stakeholders are informed and involved both in the decision-making phases as well as the other phases of the organizational process.

\section{Bottom-Up}

"I would look for a comparison with everyone because even if one of these stakeholders say we are obliged to participate, then it could negatively influence the event." Gr1-member2

\section{Top-Down}

“The words only create wind. So you let more people talk about who doesn't understand anything and less and finish it." Gr2-member1

\section{$\underline{\text { Involvement }}$}

"I think we should always seek dialogue with everyone, especially with those you hope can work with you. I don't think the decision taken from above could work." Gr2-member4

\section{RETURN}

This sub-theme likewise sparked a lively debate about the returns generated by an event and whether the rewards should go to a single and specific stakeholder or to the valley and the whole community. This second option seemed to prevail even though "community" did not feature as a stakeholder in the word cloud.

\section{Collective}

"It seems to me a very transversal, contained return but that has touched and given a bit of benefit to everyone." Gr2-member3

$\underline{\text { Single }}$

"I believe that ski clubs have also benefited a lot from the growth of technicians and children... Also in relation to the national and international federation they have a great event in the curriculum and they are ready to do other great events as well." Gr2-member5

\subsubsection{Outcome of the Focus Groups Discussion}

In the focus groups exploring the residents' perceptions of the small-scale sports event, many positive effects were acknowledged. Many respondents suggest a bottom-up approach in managing stakeholders in small-scale sports events similar to JWC2019, considering this the only way to achieve full community involvement. Moreover, they expressed the view that the main return from the event should not be attributed to a single stakeholder but to the community as a whole and to the territorial socio-economic system. This was seen not only as a fact with respect to the event being 
studied, but also as an expectation among all the interviewees for future events. The residents also state that the organizers of small-scale sports events should adopt a clear strategy from the start to identify and involve all interested stakeholders in the event.

There is absolutely no doubt that the sustainability problem is important for the future and, in the focus group discussion, it appeared as a "must" among the keywords in Figure 3c. For some residents, sustainability will be a key element in the future. When the community is involved by the event organizers, it tends to favor the sustainability of the community itself through collective objectives. In this case, the residents are fully aware of living in an extraordinary environment and a precious tourist destination, but they are equally aware that this is a precarious balance. It is evident that they feel the need to do something, but do not really know how to tackle the issue and, above all, who should take responsibility.

The potential of sports events in terms of the return for a destination is very clear. However, the implications that a sports event has for the whole community's quality of life are equally clear to residents, who hold the view that, hosting several small-scale sports events could bring greater benefits than hosting larger, more impactful events in the area.

\subsection{Overall Findings}

\subsubsection{The Residents' Perception of Small-Scale Sports Events}

The present study has investigated the perspective of the residents and that of the other stakeholders in an attempt to highlight any differences and to understand their motivations. From the data emerging from the questionnaire, residents differ from tourists and other stakeholders in terms of their perceptions about the event and its strengths. Regarding perceptions related to the territory, the three stakeholder groups do not seem to have systematically different opinions. Qualitative analysis reveals that residents do not see themselves as stakeholders. Most of the focus group residents hope that the approach to stakeholder management of sporting events will be bottom-up. This aspect is closely connected to that of the benefits which, according to residents, should not be attributed to a single stakeholder, but to the community as a whole, and, therefore, become a collective benefit.

\subsubsection{Sustainability for Residents}

The surveys show a general satisfaction among residents and other stakeholders with respect to the tourist destination. The stakeholders' perceptions of the territory are all positive and the evaluations high. The environment and the landscape are perceived in a transversal manner as very important assets. Focus groups have identified keywords such as 'mountains', 'nature' and 'tourism' (Figure 3a). The interviewees were fully aware that a vision of sustainable tourism has great value for the tourist destination. An aspect that does not appear as a priority is that of sustainability in the context of the JWC2019. When we talk about sports events and the future, for many residents the concept of sustainability appears very important. Residents are aware of the need for sustainable tourism development through sports events, also in the context of mobility, environmental protection and community involvement.

\subsubsection{Small-Scale Sports Events and Mega Events}

The questionnaires show that residents differ from tourists and other stakeholders in their perceptions of JWC2019 and its strengths. It is very clear to residents that it was a youth event but not for this reason considered "minor". It is clear for residents that a small-scale sports event is also a great opportunity to promote tourism. This study did not aim to measure the actual return on investment of the sports event, even if on a small scale. Rather, this study intends to shed light on perceptions with respect to a choice to organize or not organize a sporting event and how. After all, such an event has implications for different aspects of the lives of the whole community. 
Table 6 summarizes the sub-themes that emerged from the focus group analysis. The awareness of most residents is that even a small-scale sports event can benefit the community and must necessarily lead to something more important. Future expectations and legacy are international accreditation and the strong desire to be considered among the top organizers of sports events with tourist value. According to residents, this should lead to an improvement in infrastructure, mobility and environmental policies aimed at managing the most critical aspects such as respect for the natural environment, perceived by all as the true great value, and as an advantage for both the tourist destination and the sporting event.

Finally, there is a feeling among the residents that they possess a strong cultural identity that should be strengthened to create a real competitive advantage. Both the quantitative and qualitative analyses show that residents pay great attention to sports events, even if they are small-scale as in the case of JWC2019. They are considered a very important driver for the development of tourism and a stimulus for major events. The Olympic Games are never mentioned (while the Alpine Skiing World Cup is often mentioned), although the destination could be influenced by its proximity to the WOG2026 Milan-Cortina and may be used as a training site.

\section{Discussion}

Inspired by recent research [4] which examined, in a pre-event perspective, the role of stakeholders in a small-scale sports event, and based on the results, this article intends to demonstrate that from a residents' perspective, a small-scale sports event can represent an opportunity to reflect upon and plan for sustainable development at a tourism-led destination, now and in the future.

\subsection{The Residents' Perception of Small-Scale Sports Events and Differences Compared to other Stakeholders}

As we have seen in numerous scientific contributions that focus on major events $[62-67,69]$, the residents' perspective must be taken into account. The present study finds some affinities to the study by Schnitzer et al. [73] where the residents were concentrated within a young age range and which took a specific look at the Olympic Games. Starting from the positions in the literature relating to the definition and subsequent adoption of the stakeholder theory $[6-8,51,53]$, the present study has certainly tried to analyze the existence of differences in the perceptions of the various actors involved in the object of the case study. First of all, we identified the stakeholders defined as "primary" based on their importance/role/influence with respect to the organization of the event itself $[56,60]$. Observing Mitchell, Agle and Wood [8] "what is needed is a theory of stakeholder identification that can reliably separate stakeholders from non-stakeholders" [8] (p. 854), the quantitative analysis identified the main event's stakeholder categories. The data emerging from the questionnaire allows us to compare these categories. As stated in the findings section, residents differ from tourists and other stakeholders in terms of their perceptions regarding the event and its strong points. When it comes to the perceptions related to the territory, the three groups do not seem to have systematically differing opinions. The qualitative analysis reveals the keywords (see Figure 3d) the residents discussed in the focus groups where, as already anticipated, the residents never selected themselves as stakeholders. Instead, the 'municipalities' of the territory, the 'tourist office' (recognized as a primary driver) and the 'sports clubs' were identified as the predominant event stakeholders. Several other local actors followed and/or were considered "equal" or recognized stakeholders in the JWC2019. Table 6 shows the main themes that emerged through the coding in the analysis of the focus groups. Here the scientific literature offers us a key to identifying stakeholders and defining an adequate strategy [54-58]. The majority of residents in the focus groups recognized a bottom-up approach to managing the stakeholders in the JWC2019 and see this mode as the most implementable for achieving complete community involvement. On the subject of "community", the majority also agreed that the main return on the event should not be attributed to a particular stakeholder, even if some specificities emerged, but to the community as a whole and the territorial socio-economic system. This was seen not only as a fact with respect to the event being studied, but also as an expectation among all respondents for future events that 
should aim for the complete involvement of the community for the sake of collective benefit. The results of the qualitative analysis confirm the perceptions of residents as well as the research of Reid and Arcodia [11], concluding that the adoption of a clear strategy to identify and involve stakeholders in the event, as well as key actions are necessary in order to create effective competitive advantages.

\subsection{Sustainability for Residents: Must Have or Nice to Have?}

Quantitative analysis shows that the destination Val di Fassa generally generates very satisfied guests and residents. Overall, the respondents gave positive feedback and high ratings for the destination and, when asked whether they would return to the destination after their first visit, the cross-sectional responses of all stakeholders (Table 5), measured with the Likert Scale, were all between 4 and 5, where 5 means very likely. Qualitative research has allowed us to take advantage of words and not just numbers [89]. In the questionnaire, some differences in the distribution among stakeholders were noted, for example, in the description of the destination or the attribution of word descriptions to the JWC2019. The focus groups identified keywords such as 'mountains', 'Dolomites', 'nature' and 'tourism' (Figure 3a). The respondents were fully aware of the region's status as a mountain tourist destination where tourism has a strong value and the promotion of the locality is of great importance. Table 6 summarizes the sub-themes that emerged from the focus grouping system. One aspect that does not appear as a priority is that of sustainability. While it is often cited when dealing with the issue of sports events, it is not mentioned in the context of destination and tourism. The quantitative results did not affect the types of participants to be selected specifically for the qualitative phase but helped to define the questions that were posed to the focus group participants. In the focus groups, no particular mention was made of the climate change issue [18]. There is absolutely no question that the sustainability issue is touched upon when considering the future and, in the focus group discussion, it appears as a "must have" among the keywords in Figure 3c. In this case there always appears to be a strong connection between sports event and promotion of the territory. The role of the organization, however, is clearly more important for a sports event as is following the contribution of the volunteers. The keyword 'sustainability', in this case environmental, that the residents consider a "must have", is an element that can no longer be ignored in the future. The focus groups show an awareness of the need for sustainable tourism development. They also hold the view that it is the responsibility of third parties or the governing bodies to tackle this issue as though it were something that could not be implemented by individuals or regular residents [90] through good daily practice. The object of the study cannot be classified as a green event where literature [33] has found that it can affect the behavior of the stakeholders and the community involved. When the community is involved by the event organizers [35], it tends to be of benefit to the sustainability of said community and of the overall tourism policies.

\subsection{Do Small-Scale Sports Events Represent a Stimulus for Hosting Mega Events?}

Higham [2] explained that hosting large-scale sports events helps in attracting a consistent number of visitors, exploiting existing infrastructures and maintaining a balance with the host community. The literature [42,91,92], however, confirms that even small-scale sports events can represent an opportunity for sustainable tourism development.

In the quantitative research it became clear that residents differ from tourists and other stakeholders in terms of their perceptions regarding the JWC2019 and its strong points. In the qualitative analysis, the author investigated the specific theme of residents. Figure $3 b$ shows that the keywords 'youth', 'competition' and 'promotion' best represent the small-scale event under investigation. The fact that it was a youth event was certainly understood and well accepted, as was the fact that a sports and competitive event is also a great opportunity for promoting tourism. The potential of sports events in terms of the return for a destination, has been analyzed and indeed, several studies have been conducted into this topic, especially in the context of mega sports events [93-95]. This study does not aim to measure an actual return on investment for a sports event, even if it is small-scale $[5,30]$. 
Based on the assessment of residents' perceptions, this study rather intends to shed more light on the stakeholders most involved in the governance of sports events so that we not only have the parameter of economic return but a complete vision with respect to a choice, that of organizing or not organizing a sports event and how. After all, such an event has implications for the quality of life of the whole community, particularly where this community has an economy based on tourism. Some authors have shown how hosting several small sports events can bring greater benefits than hosting one or larger ones $[45,46]$. The purpose of this study is rather to understand how a small-scale sports event is perceived by residents and whether it can inspire them to bid for and host larger-scale sports events, without entering into the merits of greater value or the minors of small or large scale.

Table 6 summarizes the sub-themes that emerged from the focus group analysis. It illustrates the contribution of powerful values associated with the sports event and the awareness among the majority of focus group residents that even a small-scale sports event can bring benefits to the community and that it must necessarily lead to something more important. The future expectation and legacy are international accreditation and the strong desire to be mapped among the great organizers of sports events with tourist value. According to the residents, this should lead to an improvement in the infrastructure and to an organizational modality that takes into account critical aspects such as respect for the natural environment, perceived by all as the true great value, and as an asset both of the tourist destination and of the sports event.

Finally, the author found confirmation that [49] "building long-term cooperation that overcomes barriers associated with local community identities helps foster participation in joint activities by efficiently combining and using limited resources that have significant social importance locally" [49] (p. 15). There is a feeling among residents that they are a small community with spatial and economic limitations, which however possesses a strong cultural identity that should be strengthened and nurtured, above all, in the younger age groups to create a true competitive advantage both in the case of sports events and in tourism communication. Both the quantitative and qualitative analysis demonstrated that intangible social dimensions may be clearer [50]. The research results reveal that the residents pay great attention to sports events, even small-scale ones. They are considered a very important tool for tourism development and a stimulus for major events.

\subsection{Practical and Theoretical Implications}

This work can assume particular importance in the scientific community and can also be a useful tool for professionals in sport and tourism wanting to establish the current state of research in a particular sector, such as small-scale sports events with tourism implications. It is clear that sports events, even on a small scale, are perceived as a positive value. It is also evident that management needs to incorporate the event in the territory's sustainable development strategies to a greater degree. From a theoretical point of view, there is a need to deepen the analysis in the category of residents with respect to sports events and to the broader theme of sustainable destination development. Previous studies in the context of local festivals have tried to evaluate their effect on sustainable development by touching upon the economic, social and environmental sphere. The present study has instead tried to understand whether the perceptions of the event stakeholders and in particular of the residents reflect a clear sense that the event should contribute to the sustainable development of the territory. The study did not want to provide timely measurements of the effects previously mentioned in relation to sustainable development but rather focused on the general perceptions of the stakeholders and in particular of the residents who constitute an increasingly decisive actor even though this group has received little consideration in the past. There is clearly a need to involve residents in every key decision and in every organizational phase of an event in order to obtain the expected benefits in terms of development of the whole territorial context. 


\subsection{Limitations}

The study certainly presents limitations, but also opportunities for further research in this subject area. In the quantitative research, the differing numbers $(\mathrm{N})$ of stakeholders represent a limitation. The group size might have an influence on the differences in distribution. The adoption of homogeneous groups has partially reduced this limitation. This study used a randomly represented sample. In future research, we could increase the number of research teams and improve our model. Future studies could sample a larger group of stakeholders to confirm whether or not our results hold true. The explanatory sequential mixed methods design approach can be deemed useful for the construction of the second phase of qualitative research. Inserting the questions specific to this research in a wider questionnaire on the quality of the event could certainly represent a limitation because it does not focus directly on the object of the research itself. We cannot confirm that there were no biases due to the questionnaire submission process, but the consistency of the data was corroborated by the subsequent qualitative analysis. Many new questions have emerged, all consistent with this research (how did the residents perceive the environmental impact of a particular event? What impact did the event have on the environment? What was the environmental burden of the event? Was the event organized in accordance with the aim of sustainable destination development? What was the residents' role in the organizing process of this particular event? How could they influence the preparation and organisation of the event?). The issue of sustainability linked to small-scale sports events must certainly be dealt with more extensively by specific studies. Certainly, the present work does not answer many of these questions, but it does provide stimulus for future research.

\section{Conclusions}

To conclude the study, the author hopes that, despite its limitations, it can represent a useful in-depth tool for sports professionals involved in events and tourism. The ambition is to be a small brick in the great bridge of knowledge in this specific field of study.

The author has always remained true to the study design throughout the research process that ultimately led to the following conclusions:

First of all, RQ1: What are the perceptions of the various stakeholders during a small-scale sports event? Do residents' perceptions match those of other stakeholders? If yes, how? There is evidence that residents differ from tourists and other stakeholders in terms of their perception regarding the event and its strong points. When it comes to the perceptions of the territory, the three groups do not seem to have systematically different opinions. The sense of belonging and the awareness of representing a unique natural and cultural heritage are strong among residents. From the focus groups, which certainly cannot be exhaustive, it becomes clear that the "residents" category does not see itself as a stakeholder. This is perhaps because the representation of residents in a democratic system is left to the political roles of local administrators. The second element that emerges is that the residents are indeed aware of the value of their territory, of its tourist value and of the importance of sports events (small in this case). There is a very broad collective maturity which also finds expression in the need for residents to share strategies and decision-making with respect to sports events. There is a full awareness that the sports event, albeit small, represented a goal that has been achieved and there is a clear desire and need to attract more events. While they do not necessarily have to be bigger, in this particular case there was a desire for continuity/constancy in the staging of events.

This study examined a small-scale sports event in a tourist destination. The concept of sustainable development could be a powerful driver also for the event itself. Indeed, it could have made it into a strategic pillar. This happens for RQ2 (in the eyes of the residents, what is the perception of sustainable development in the context of a small-scale sports events in a tourist destination? Is it considered a "must have"?). The concept of sustainability is rarely addressed by residents especially when it comes to the future or legacy of the event. This finding emerged in the qualitative research that explored these issues very deeply. The paradox is, however, that in the quantitative research all categories, with some differences, referred to the environment, the mountains, nature and the landscape, as the 
destination's important assets (Val di Fassa). This is confirmed by the residents in the qualitative focus groups, where nature and environment top the list both in the keywords and in the discussion in which they described their location. By contrast, in the "must haves" for sports events, organization and promotion were the most widely shared themes. The discussion also reveals issues relating to cultural identity and the transformation of the same into tourist promotion assets, but the aspect of sustainability of events remains slightly underestimated. When it does emerge, it does so only in the environmental sphere but not as a development concept within the whole community.

Finally, the author's objective was to shed light on RQ3: What role may small-scale sports events play when hosting mega events? Does a small-scale sports event represent a development stimulus for a tourist destination? The small-scale sports event was positively experienced by the residents, just as there was a general and transverse appreciation among all stakeholders in the quantitative research. The desire to aspire to something more was certainly given. It emerged clearly and without the need for interpretation in the focus group discussions. The Olympic Games were referred to only a few times, even though Italy has been assigned the WOG2026 Milan-Cortina. Indeed, Val di Fassa borders on the Olympic sites and is preparing to host training sessions for the athletes. While other important events were mentioned (Alpine Ski World Cup) there is a strong desire for constancy and continuity in the proposal for and management of sports events. They are seen and recognized as important assets in terms of tourism, but according to residents they need to be part of a strategy (tourism vision) and long-term and continuous planning in order to release the full potential of positive effects.

Funding: This research received funding from the Doctoral programme Tourism and Leisure in Mountain Regions (TLMR) of the University of Innsbruck-Austria and from Vice Rector of Research of the University of Innsbruck-Austria.

Acknowledgments: Special thanks to the Organizing Committee of the World Junior Alpine Ski Championships Val di Fassa 2019, and to the APT Val di Fassa (Tourist Board). The author thanks the high school Istituto La Rosa Bianca in Predazzo, the principals, teachers and students for their support and willingness to participate in the survey submission process. Furthermore, the author thanks the whole team of experts who collaborated in the survey process and those who offered inspiring comments on an earlier draft of this paper. Thanks to the Doctoral programme Tourism and Leisure in Mountain Regions (TLMR) of the University of Innsbruck-Austria and to the Vice Rector of Research of the University of Innsbruck-Austria.

Conflicts of Interest: The author declares no conflict of interest.

\section{References}

1. Getz, D. Event tourism: Definition, evolution, and research. Tour. Manag. 2008, 29, 403-428. [CrossRef]

2. Higham, J. Commentary-Sport as an Avenue of Tourism Development: An Analysis of the Positive and Negative Impacts of Sport Tourism. Curr. Issues Tour. 1999, 2, 82-90. [CrossRef]

3. Cantelon, H.; Letters, M. The Making of the IOC Environmental Policy as the Third Dimension of the Olympic Movement. Int. Rev. Sociol. Sport 2000, 35, 294-308. [CrossRef]

4. Bazzanella, F.; Peters, M.; Schnitzer, M. The perceptions of stakeholders in small-scale sporting events. J. Conv. Event Tour. 2019, 20, 261-286. [CrossRef]

5. Kwiatkowski, G.; Oklevik, O. Primary Economic Impact of Small-scale Sports Events. Event Manag. 2017, 21, 269-280. [CrossRef]

6. Freeman, R.E. Strategic Management: A Stakeholder Approach; Pitman: Boston, MA, USA, 1984.

7. Clarkson, M.B.E. A Stakeholder Framework for Analyzing and Evaluating Corporate Social Performance. Acad. Manag. Rev. 1995, 20, 92. [CrossRef]

8. Mitchell, R.K.; Agle, B.R.; Wood, D.J. Toward a Theory of Stakeholder Identification and Salience: Defining the Principle of Who and What Really Counts. Acad. Manag. Rev. 1997, 22, 853. [CrossRef]

9. Savage, G.T.; Nix, T.W.; Whitehead, C.J.; Blair, J.D. Strategies for assessing and managing organizational stakeholders. AMP 1991, 5, 61-75. [CrossRef]

10. Polonsky, M. Stakeholder management and the stakeholder matrix: Potential strategic marketing tools. J. Mark. Focused Manag. 1996, 1, 209-229. [CrossRef] 
11. Reid, S.; Arcodia, C. Understanding the role of the stakeholder in event management. J. Sport Tour. 2002, 7, 20-22. [CrossRef]

12. Van Niekerk, M. The Applicability and Usefulness of the Stakeholder Strategy Matrix for Festival Management. Event Manag. 2016, 20, 165-179. [CrossRef]

13. Byrd, E.T. Stakeholders in sustainable tourism development and their roles: Applying stakeholder theory to sustainable tourism development. Tour. Rev. 2007, 62, 6-13. [CrossRef]

14. Preuss, H.; Arne Solberg, H. Attracting Major Sporting Events: The Role of Local Residents. Eur. Sport Manag. Q. 2006, 6, 391-411. [CrossRef]

15. Nunkoo, R.; So, K.K.F. Residents' Support for Tourism: Testing Alternative Structural Models. J. Travel Res. 2016, 55, 847-861. [CrossRef]

16. Travel \& Tourism Economic Impact 2019 World; World Travel \& Tourism Council (WTTC): London, UK, 2019.

17. Duglio, S.; Beltramo, R. Mountain tourism in Europe. Eur. J. Tour. Res. 2019, 22, 129.

18. Steiger, R.; Scott, D.; Abegg, B.; Pons, M.; Aall, C. A critical review of climate change risk for ski tourism. Curr. Issues Tour. 2019, 22, 1343-1379. [CrossRef]

19. Gibson, H.J. Active sport tourism: Who participates? Leis. Stud. 1998, 17, 155-170. [CrossRef]

20. Gibson, H.J. Sport Tourism: An Introduction to the Special Issue. J. Sport Manag. 2003, 17, 205-213. [CrossRef]

21. Weed, M. Sports Tourism Experiences. J. Sport Tour. 2008, 13, 1-4. [CrossRef]

22. Deery, M.; Jago, L.; Fredline, L. Sport tourism or event tourism: Are they one and the same? J. Sport Tour. 2004, 9, 235-245. [CrossRef]

23. Chalip, L.; Costa, C.A. Sport Event Tourism and the Destination Brand: Towards a General Theory. Sport Soc. 2005, 8, 218-237. [CrossRef]

24. Van Rheenen, D.; Cernaianu, S.; Sobry, C. Defining sport tourism: A content analysis of an evolving epistemology. J. Sport Tour. 2017, 21, 75-93. [CrossRef]

25. Higham, J.; Hinch, T. Sport Tourism Development, 3rd ed.; Channel View Books: Bristol, UK, 2018.

26. Askew, A.E.; Bowker, J.M. Impacts of Climate Change on Outdoor Recreation Participation: Outlook to 2060. JPRA 2018, 36, 97-120. [CrossRef]

27. Mitcham, C. The concept of sustainable development: Its origins and ambivalence. Technol. Soc. 1995, 17, 311-326. [CrossRef]

28. Holden, E.; Linnerud, K.; Banister, D. Sustainable development: Our Common Future revisited. Glob. Environ. Chang. 2014, 26, 130-139. [CrossRef]

29. Duran, D.C.; Artene, A.; Gogan, L.M.; Duran, V. The Objectives of Sustainable Development-Ways to Achieve Welfare. Procedia Econ. Financ. 2015, 26, 812-817. [CrossRef]

30. Duglio, S.; Beltramo, R. Estimating the Economic Impacts of a Small-Scale Sport Tourism Event: The Case of the Italo-Swiss Mountain Trail CollonTrek. Sustainability 2017, 9, 343. [CrossRef]

31. Hardy, A.L.; Beeton, R.J.S. Sustainable Tourism or Maintainable Tourism: Managing Resources for More Than Average Outcomes. J. Sustain. Tour. 2001, 9, 168-192. [CrossRef]

32. Butler, R.W. Sustainable tourism: A state-of-the-art review. Tour. Geogr. 1999, 1, 7-25. [CrossRef]

33. Tölkes, C.; Butzmann, E. Motivating Pro-Sustainable Behavior: The Potential of Green Events-A Case-Study from the Munich Streetlife Festival. Sustainability 2018, 10, 3731. [CrossRef]

34. Elkington, J. Towards the Sustainable Corporation: Win-Win-Win Business Strategies for Sustainable Development. Calif. Manag. Rev. 1994, 36, 90-100. [CrossRef]

35. Negruşa, A.L.; Toader, V.; Rus, R.V.; Cosma, S.A. Study of Perceptions on Cultural Events' Sustainability. Sustainability 2016, 8, 1269. [CrossRef]

36. O'Sullivan, D.; Jackson, M.J. Festival Tourism: A Contributor to Sustainable Local Economic Development? J. Sustain. Tour. 2002, 10, 325-342. [CrossRef]

37. Quinn, B. Problematising Festival Tourism: Arts Festivals and Sustainable Development in Ireland. J. Sustain. Tour. 2006, 14, 288-306. [CrossRef]

38. Poczta, J.; Malchrowicz-Mośko, E. Modern Running Events in Sustainable Development—More than Just Taking Care of Health and Physical Condition (Poznan Half Marathon Case Study). Sustainability 2018, 10, 2145. [CrossRef] 
39. Walo, M.; Bull, A.; Breen, H. Achieving economic benefit at local events: A case study of a local sports event. Festiv. Manag. Event Tour. 1996, 4, 95-106. [CrossRef]

40. Wilson, R. The economic impact of local sport events: Significant, limited or otherwise? A case study of four swimming events. Manag. Leis. 2006, 11, 57-70. [CrossRef]

41. Taks, M. Social sustainability of non-mega sport events in a global world 1. Eur. J. Sport Soc. 2013, 10, 121-141. [CrossRef]

42. Gibson, H.J.; Kaplanidou, K.; Kang, S.J. Small-scale event sport tourism: A case study in sustainable tourism. Sport Manag. Rev. 2012, 15, 160-170. [CrossRef]

43. Gratton, C.; Dobson, N.; Shibli, S. The economic importance of major sports events: A case-study of six events. Manag. Leis. 2000, 5, 17-28. [CrossRef]

44. Yusof, A.; Omar-Fauzee, M.S.; Shah, P.M.; Geok, S.K. Exploring Small-Scale Sport Event Tourism in Malaysia. Res. J. Int. Stud. 2009, 9, 47-58.

45. Agha, N.; Taks, M. A Theoretical Comparison of the Economic Impact of Large and Small Events. Int. J. Sport Financ. 2015, 10, 199-216.

46. Giampiccoli, A.; Lee, S.S.; Nauright, J. Destination South Africa: Comparing global sports mega-events and recurring localised sports events in South Africa for tourism and economic development. Curr. Issues Tour. 2015, 18, 229-248. [CrossRef]

47. Orr, M.; Schneider, I. Substitution interests among active-sport tourists: The case of a cross-country ski event. J. Sport Tour. 2018, 22, 315-332. [CrossRef]

48. O'Brien, D. Points of Leverage: Maximizing Host Community Benefit from a Regional Surfing Festival. Eur. Sport Manag. Q. 2007, 7, 141-165. [CrossRef]

49. Perić, M.; Đurkin, J.; Wise, N. Leveraging Small-Scale Sport Events: Challenges of Organising, Delivering and Managing Sustainable Outcomes in Rural Communities, the Case of Gorski kotar, Croatia. Sustainability 2016, 8, 1337. [CrossRef]

50. Malchrowicz-Mośko, E.; Poczta, J. A Small-Scale Event and a Big Impact-Is This Relationship Possible in the World of Sport? The Meaning of Heritage Sporting Events for Sustainable Development of Tourism-Experiences from Poland. Sustainability 2018, 10, 4289. [CrossRef]

51. Lim, G.; Ahn, H.; Lee, H. Formulating strategies for stakeholder management: A case-based reasoning approach. Expert Syst. Appl. 2005, 28, 831-840. [CrossRef]

52. Freeman, R.E. The Stakeholder Approach Revisited. ZFWU 2004, 5, 228-241. [CrossRef]

53. Fassin, Y. A Dynamic Perspective in Freeman's Stakeholder Model. J. Bus. Ethics 2010, 96, 39-49. [CrossRef]

54. Mossberg, L.; Getz, D. Stakeholder Influences on the Ownership and Management of Festival Brands. Scand. J. Hosp. Tour. 2006, 6, 308-326. [CrossRef]

55. Andersson, T.D.; Getz, D. Stakeholder Management Strategies of Festivals. J. Conv. Event Tour. 2008, 9, 199-220. [CrossRef]

56. Parent, M.M.; Kristiansen, E.; Skille, E.Å.; Hanstad, D.V. The sustainability of the Youth Olympic Games: Stakeholder networks and institutional perspectives. Int. Rev. Soc. Sport 2015, 50, 326-348. [CrossRef]

57. Van Niekerk, M.; Getz, D. The Identification and Differentiation of Festival Stakeholders. Event Manag. 2016, 20, 419-431. [CrossRef]

58. Amaral, C.M.; Dos, S.; Bastos, F.D.C.; Carvalho, M.M. Mapeamento de stakeholders em projetos de eventos esportivos: Estudio de caso. Podium Sport Leis. Tour. Rev. 2018, 7, 22-45. [CrossRef]

59. Getz, D.; Andersson, T.; Larson, M. Festival Stakeholder Roles: Concepts and Case Studies. Event Manag. 2006, 10, 103-122. [CrossRef]

60. Beritelli, P.; Laesser, C. Power dimensions and influence reputation in tourist destinations: Empirical evidence from a network of actors and stakeholders. Tour. Manag. 2011, 32, 1299-1309. [CrossRef]

61. Volo, S. Conceptualizing Experience: A Tourist Based Approach. J. Hosp. Mark. Manag. 2009, 18, 111-126. [CrossRef]

62. Bull, C.; Lovell, J. The Impact of Hosting Major Sporting Events on Local Residents: An Analysis of the Views and Perceptions of Canterbury Residents in Relation to the Tour de France 2007. J. Sport Tour. 2007, 12, 229-248. [CrossRef]

63. Zhou, Y.; Ap, J. Residents' Perceptions towards the Impacts of the Beijing 2008 Olympic Games. J. Travel Res. 2009, 48, 78-91. [CrossRef] 
64. Boo, S.; Wang, Q.; Yu, L. Residents' Support of Mega-Events: A Reexamination. Event Manag. 2011, 15, 215-232. [CrossRef]

65. Al-Emadi, A.; Kaplanidou, K.; Diop, A.; Sagas, M.; Le, K.T.; Al-Ali Mustafa, S. 2022 Qatar World Cup: Impact Perceptions among Qatar Residents. J. Travel Res. 2017, 56, 678-694. [CrossRef]

66. Gursoy, D.; Yolal, M.; Ribeiro, M.A.; Panosso Netto, A. Impact of Trust on Local Residents' Mega-Event Perceptions and Their Support. J. Travel Res. 2017, 56, 393-406. [CrossRef]

67. Vetitnev, A.M.; Bobina, N. Residents' perceptions of the 2014 Sochi Olympic Games. Leis. Stud. 2017, 36, 108-118. [CrossRef]

68. Gursoy, D.; Kendall, K.W. Hosting mega events. Ann. Tour. Res. 2006, 33, 603-623. [CrossRef]

69. Chen, F.; Tian, L. Comparative study on residents' perceptions of follow-up impacts of the 2008 Olympics. Tour. Manag. 2015, 51, 263-281. [CrossRef]

70. Deccio, C.; Baloglu, S. Nonhost Community Resident Reactions to the 2002 Winter Olympics: The Spillover Impacts. J. Travel Res. 2002, 41, 46-56. [CrossRef]

71. Ruiz, E.C.; De la Cruz, E.R.R.; Vázquez, F.J.C. Sustainable Tourism and Residents' Perception towards the Brand: The Case of Malaga (Spain). Sustainability 2019, 11, 292. [CrossRef]

72. Foroni, I.; Modica, P.; Zenga, M. Residents' Satisfaction with Tourism and the European Tourism Indicator System in South Sardinia. Sustainability 2019, 11, 2243. [CrossRef]

73. Schnitzer, M.; Walde, J.; Scheiber, S.; Nagiller, R.; Tappeiner, G. Does the young residents' experience with the Youth Olympic Games influence the support for staging the Olympic Games? Tour. Manag. Perspect. 2019, 30, 220-231. [CrossRef]

74. Annuario del Turismo 2018, Provincia Autonoma di Trento. Available online: http://www.statweb.provincia. tn.it/incpage.asp? $\mathrm{p}=$ annuari.asp\&t=ann (accessed on 25 July 2019).

75. Creswell, J.W. Research Design: Qualitative, Quantitative, and Mixed Methods Approaches; SAGE: London, UK, 2013.

76. Tashakkori, A.; Teddlie, C. Handbook of Mixed Methods in Social \& Behavioral Research; SAGE: London, UK, 2003.

77. Bryman, A. Integrating quantitative and qualitative research: How is it done? Qual. Res. 2006, 6, 97-113. [CrossRef]

78. Fetters, M.D.; Curry, L.A.; Creswell, J.W. Achieving Integration in Mixed Methods Designs-Principles and Practices. Health Serv. Res. 2013, 48, 2134-2156. [CrossRef] [PubMed]

79. Tashakkori, A.; Teddlie, C. Mixed Methodology: Combining Qualitative and Quantitative Approaches; SAGE: London, UK, 1998.

80. Teddlie, C.; Yu, F. Mixed Methods Sampling: A Typology with Examples. J. Mix. Methods Res. 2007, 1, 77-100. [CrossRef]

81. Krueger, R.A. Focus Groups: A Practical Guide for Applied Research, 2nd ed.; Sage Publications: Thousand Oaks, CA, USA; London, UK, 1994.

82. Glaser, B.G.; Strauss, A.L. The Discovery of Grounded Theory: Strategies for Qualitative Research; Paperback Printing: New Brunswick, NB, Canada, 2009.

83. Mason, M. Sample Size and Saturation in PhD Studies Using Qualitative Interviews. Forum Qual. Soz. Forum Qual. Soc. Res. 2010, 11, 3.

84. Krueger, R.A.; Casey, M.A. Focus Groups: A Practical Guide for Applied Research, 4th ed.; SAGE Publications: Los Angeles, CA, USA, 2008.

85. Scott, J. Social Network Analysis: A Handbook, 2nd ed.; SAGE Publications: London, UK; Thousands Oaks, CA, USA, 2000.

86. Veal, A.J. Research Methods for Leisure and Tourism, 4th ed.; Financial Times/Prentice Hall: Harlow, UK, 2011.

87. Mayring, P. Qualitative Content Analysis. Forum Qual. Soz. Forum Qual. Soc. Res. 2000, 1, 2.

88. Oprandi, N.C. Focus Group, 2nd ed.; Emme\&erre Libri: Padova, Italy, 2001.

89. Creswell, J.W. Qualitative Inquiry and Research Design: Choosing Among Five Traditions; Sage Publications: Thousand Oaks, CA, USA, 1998.

90. Kollmuss, A.; Agyeman, J. Mind the Gap: Why do people act environmentally and what are the barriers to pro-environmental behavior? Environ. Educ. Res. 2002, 8, 239-260. [CrossRef]

91. Fredline, E. Host and Guest Relations and Sport Tourism. Sport Soc. 2005, 8, 263-279. [CrossRef]

92. Fyall, A.; Jago, L. Sustainability in Sport \& Tourism. J. Sport Tour. 2009, 14, 77-81. 
93. Schnitzer, M.; Kristiansen, E.; Hanstad, D.V. Comparing the expectations, experiences and legacies of volunteers at the FIS Nordic World Ski Championships in Oslo 2011 and Val di Fiemme 2013. Curr. Issues Sport Sci. 2018, 3, 1-11.

94. Preuss, H. The Conceptualisation and Measurement of Mega Sport Event Legacies. J. Sport Tour. 2007, 12, 207-228. [CrossRef]

95. Leopkey, B.; Parent, M.M. Olympic Games Legacy: From General Benefits to Sustainable Long-Term Legacy. Int. J. Hist. Sport 2012, 29, 924-943. [CrossRef]

(C) 2019 by the author. Licensee MDPI, Basel, Switzerland. This article is an open access article distributed under the terms and conditions of the Creative Commons Attribution (CC BY) license (http://creativecommons.org/licenses/by/4.0/). 